\title{
Do People Deserve their Economic Rents?
}

\author{
THOMAS MULLIGAN \\ Georgetown University
}

\begin{abstract}
Rather than answering the broad question, 'What is a just income?', in this essay I consider one component of income-economic rent-under one understanding of justice-as giving people what they deserve. As it turns out, the answer to this more focused question is 'no'. People do not deserve their economic rents, and there is no bar of justice to their confiscation. After briefly covering the concept of desert and explaining what economic rents are, I analyze six types of rent and show that each is unjustified from the point of view of desert. I conclude by drawing some political and economic lessons from the preceding analysis, and by describing how these considerations can create a more just and efficient economy.
\end{abstract}

Keywords: desert, economic rent, economic contribution, public policy

JEL Classification: D24, D33, D63, J30

\section{INTRODUCTION}

The question 'What is a just income?' is a difficult one to answer, not least because it is ambiguous in two ways. First, it does not say what justice is. And of course there is no consensus about this. Second, 'income' refers to many different flows of money, and we may want to differentiate between these for the purpose of moral analysis. Wages, dividends and interest from an inheritance, government transfers, and other forms of income have unique moral features.

Rather than try to cover all that conceptual ground, I devote this essay to considering one component of income-economic rent-under one specification of justice-as giving people what they deserve. In this way, the problem is made a little more tractable. Therefore, we shall proceed under the assumption that the desert-based approach to justice,

AUTHOR's NoTE: I thank Jim Albrecht, Huub Brouwer, Willem van der Deijl, Ryan Patrick Hanley, Rob Hughes, and David Levy for helpful conversations about the matters discussed herein, along with two anonymous referees, who provided helpful advice. I am also grateful to the audience at the Wharton School of Business' 2018 Normative Business Ethics Workshop. 
which I outline but do not defend in §2, is correct. (For this defense, see Mulligan 2018.)

I do not think that these limitations render the project unimportant. Quite the opposite: I expect desert to command increasing interest, among both philosophers and the public, in coming years. And a major part of what is amiss with many contemporary economies-in terms of their justness and their efficiency-is the prevalence of rent. This will be discussed in due course.

Because the moral problem I seek to illuminate is most acute in the United States, and because much of the relevant empirical research concerns the U.S. (and because, I concede, of my own nationalistic spirit), I shall focus on the American economy. But of course the moral argument applies without regard to nationality, and the problem exists to some degree in the Netherlands, in Germany, and everywhere else. If you ask me what explains the disproportionate presence of economic rent in the American economy, I do not know but conjecture three things.

First, equal opportunity in the U.S. badly lags (the U.S. may now have the worst intergenerational mobility in the developed world), ${ }^{1}$ which has generated myriad opportunities for appropriating rents. Second, Americans today tend to be more libertarian and less civic-minded than their counterparts on the Continent; we are more tolerant of incomes that are legal but economically unproductive. Third, many European tax schedules do a better job of disincentivizing rent extraction than the U.S. tax schedule does-through, especially, higher top marginal income tax rates.

I have organized this essay as follows. In §2, I describe the concept of desert and outline the desert-based theory of distributive justice on which I rely. \$3 is devoted to explaining what economic rents are. $\$ 4$ is the heart of the essay: I analyze several real-world cases of rent extraction and show that this form of income is undeserved. I conclude in $\$ 5$ by discussing the political and economic ramifications of the preceding analysis.

\section{THE CONCEPT OF DESERT}

John Hospers once mused, "justice is getting what one deserves; what could be simpler?" (1961, 433). But (as Hospers knew well), this is anything but true-desert is a rich but difficult concept which has

\footnotetext{
${ }^{1}$ See, e.g., Corak (2013) and Mazumder (2005).
} 
resisted analysis for millennia. Nevertheless, we have learned some things; enough, at least, to make sense of arguments about what people do or do not deserve. ${ }^{2}$

The received wisdom is that desert is a three-place relation, consisting of (1) a desert subject, (2) a desert object, and (3) a desert basis. We say things like, 'Jane deserves the medal on the basis of her performance'. Here, Jane is the desert subject, the medal is the desert object, and her performance is the desert basis. Although sometimes we leave one or more of these elements implicit-'He deserves it!' does not specify a desert basis-they are always there. If it is claimed that Sandra deserves the job, and someone asks, 'On what grounds?', it would make no sense to respond, 'No reason; she just does'. Unless there is a reason why Sandra is deserving, 'Sandra deserves the job' is not a desert-claim at all but something like an expression of approval.

It is further accepted that there are important conceptual connections between (1) and (2), (2) and (3), and (1) and (3). We shall just consider the last: the relation between desert subject and desert basis. Its strength is debated. Some scholars believe that desert subjects must be responsible for their bases (e.g. Rachels 1978). Others, that they must control their bases (Sadurski 1985). We shall rely on the weakest, and least controversial, construal of the relation-what is sometimes known as the aboutness principle (Feinberg 1963). To wit, the desert basis must be about the desert subject. Fred cannot deserve jail on the basis of David's crimes. Lane cannot deserve the scholarship on the basis of her sister's transcript. And so on. This is obvious.

What is not obvious is how desertism diverges from other theories of distributive justice, and I think that is worth pointing out here. Let us consider an archetypical desert-claim: Jones deserves the job on the basis of his merit. Note, first, that this is a fully deontological notion: if one is in charge of this distributive decision, one should scrutinize the merits of the job applicants, figure out which applicant is the most meritorious among them, and then award that applicant the job. ${ }^{3}$ That is the moral rule, and one acts justly if one follows that rule.

\footnotetext{
${ }^{2}$ The seminal conceptual analyses of desert are Feinberg (1963), Kleinig (1971), and Sher (1987).

${ }^{3}$ There are contexts in which desert is a comparative notion. Other contexts are wholly non-comparative. Some contexts (like this one) are both; the best-qualified applicant among several might fail to meet a non-comparative standard of merit, and thereby not be deserving. Issues of comparative $v$. non-comparative desert are covered in extreme detail in Kagan (2012). Olsaretti (2003) is also helpful.
} 
Now consider: Does the utilitarian demand that we give the most meritorious applicant the job? No, because it is conceptually possible that the general welfare is promoted by deviating from merit-based hiring. Indeed, this appears true in practice: some citizens have a "taste for discrimination" (Becker 1957), preferring to patronize or work alongside members of a particular race. As a result, firm profits and the social surplus may increase when firms hire less meritorious applicants on account of their race. It is possible that race-based discrimination will lead to a maximally happy world.

Libertarians like Robert Nozick (1974) do not require that the most meritorious applicant be hired. Firm owners are putatively at liberty to contract as they see fit. If a firm owner is racist, there is no bar of justice, on this libertarian account, to his excluding members of that race from his firm-no matter their merits.

Theorists of an egalitarian bent are often happy to violate meritocratic hiring. This may be seen in, for example, academic hiring, where less meritorious women are preferred over more meritorious men in the name of creating a workforce with a certain gender make-up (viz. one with the same proportion of men to women as exists in the general population). ${ }^{4}$

John Rawls' (1971) egalitarian approach may also condone hiring on the basis of features irrelevant from the point of view of merit, like race and gender. This is for reasons similar to the utilitarian's: not output per se, but the portion of it claimed by the least advantaged, may be maximized by adhering to a hiring rule that is not perfectly meritocratic. In such a case, the Difference Principle will select that rule. ${ }^{5}$

For the desertist, none of these justifications holds water. It is categorically unjust to discriminate on the basis of race. It is categorically unjust to discriminate on the basis of gender. These features are irrelevant from the point of view of merit in virtually all hiring contexts. (An exception would be, e.g., a firm seeking to hire

\footnotetext{
${ }^{4}$ See, e.g., Allen-Hermanson (2017), Dicey Jennings et al. (2015), and Williams and Ceci (2015). The data are incompatible with the notion that gender preference only nullifies bias against women. (If that were the case, then the 'preference' would be justified-see Mulligan 2018, 205.)

5 Matters are complicated by the fact that preferential hiring might implicate opportunity as well as income, and thereby fall, at least in part, under Rawls' Fair Equality of Opportunity Principle (which takes lexical priority over the Difference Principle). It is very unclear what Rawls would say about the case of taste discrimination I consider here. His own views of race-based hiring were apparently nuanced-see Freeman (2007). I thank an anonymous referee for pointing this out to me.
} 
someone to model women's clothes.) Because desert is deontological, no forward-looking justifications, like those given by the utilitarian or the Rawlsian, will work. And there is no foundational place for protecting the alleged liberty interest of firm owners.

The argument of this essay relies on one conception of the idea that justice is a matter of giving people what they deserve. This conception understands desert in meritocratic terms. Another conception might understand desert in terms of need. And under that conception, it is not the most meritorious candidate who deserves the job, but the candidate who needs the job the most (cf. Feldman 2016). Nevertheless, this is not much of a loss of generality, since the meritocratic conception of justice-as-desert is the most natural and, I think, the most popular. And it is the conception which the originator of desert-based justiceAristotle-had in mind.

Two final preparatory remarks. First, desert is a pre-institutional concept. Although 'desert' and its cognates are sometimes used, sloppily, to mean 'proper under the rules', this is a mistake. People's deserts are determined independent of what the rules say. And the rules ought to be written so that people get what they deserve-not the other way around.

Imagine, for example, an executive who signs a contract to manage a company for a year in exchange for $€ 50$ million. Over the course of that year, the executive becomes a lazy drunkard, and his bad decisionmaking bankrupts the company. Nevertheless, he does what is required of him under his (poorly-written) contract. We would not say that he deserves the $€ 50$ million because that is what the contract says. No: the executive is undeserving. He does not deserve that $€ 50$ million-he is merely entitled to it. Those of us of a desertist bent would encourage firms to write better contracts, so that undeserving people do not become entitled to large sums of money, as is the case here.

Second, it is clear that the proper desert basis differs from context to context; what makes one deserving of the gold medal (viz. athletic performance) is different from what makes one deserving of jail (commission of a crime). And we want to know about the distribution of income here.

There is no consensus among desert scholars (such as we, the happy few, are) about this, but the most prominent view, and the one which I subscribe to, is that people deserve income on the basis of their economic contributions (see, e.g., Miller 1976, 1989, and 1999; Riley 
1989). I argue for this elsewhere (Mulligan 2018), so I'll simply point out here three broad reasons why contribution should be preferred. First, it is the basis that comports with our pre-theoretical judgments about what people deserve. Second, the two other possible bases, cost (Ake 1975; Dick 1975; Lamont 1997) and effort (Milne 1986; Sadurski 1985), have conceptual problems. ${ }^{6}$ And third, contribution most nicely aligns with (ideal) market-based distribution, and is-quite apart from any considerations of justice-desirable on consequentialist grounds. ${ }^{7}$

Nevertheless, the analysis of economic rent in $\S 4$ suggests that economic contribution simpliciter cannot be the proper desert basis. Sometimes, even when people's rents do reflect a bona fide contribution, they are undeserved. In this way, analysis of rent sheds new light on the concept of desert.

\section{WhAt ARE ECONOMIC RENTS?}

When it is discussed at all, 'economic rent' is typically defined as unearned income. ${ }^{8}$ This is unhelpful. For one thing, 'unearned income' is itself ambiguous. And insofar as 'unearned income' does have a precise definition-namely, the one provided by law (in the U.S., at 26 USC §32(c)(2)(A)) - it is not coextensive with economic rent. Star baseball player Clayton Kershaw's \$33 million salary is all earned income in the eyes of the Internal Revenue Service, but it is mostly economic rent.

For these reasons and others to be made plain in the next section, typical definitions of economic rent-'income that required no effort to obtain', 'income gained through luck', 'income unconnected to skill'will not do.

Before settling on the precise, neoclassical definition of 'economic rent', we can get a sense of what rent is, and how it is obtained, by considering how classical economists thought about the phenomenon.

\footnotetext{
${ }^{6}$ Lamont (1997) argues that rents are undeserved because they do not serve to compensate people for incurred costs. I shall not address his argument here.

${ }^{7}$ For discussion of this matter-selection of the proper economic desert basis-see, inter alia, Hurka (2003), Lamont (1995), McLeod (1996), Miller (1989), Milne (1986), Mulligan (2018), Olsaretti (2004), and Sadurski (1985).

${ }^{8}$ Because 'economic rent' is such an odd term, I conducted a limited investigation of its etymology. That investigation was unsuccessful. The term goes back to Smith, at least, but I do not know if he coined it. It is also unclear whether the concept has the name that it does because of its close connection to land ownership, or whether its originator recognized that all fixed factors of production would have a rental rate analogous to that of land. Consultations with economic historians failed to shed light on this matter.
} 
For them, economic rent was income gained through ownership of land and other 'free gifts of nature'. For example, Adam Smith says that:

[...] as soon as the land of any country has all become private property, the landlords, like all other men, love to reap where they never sowed, and demand a rent even for its natural produce. The wood of the forest, the grass of the field, and all the natural fruits of the earth, which, when land was in common, cost the labourer only the trouble of gathering them, come, even to him, to have an additional price fixed upon them. He must then pay for the licence to gather them; and must give up to the landlord a portion of what his labour either collects or produces. This portion, or, what comes to the same thing, the price of this portion, constitutes the rent of land (Smith 1784, 74-75).

There are a few things to note about Smith's scenario. First, we have someone who is obtaining an income through ownership: a landlord charges for the use of his land. Second, the owned good is sought for the purpose of production: the laborer wants to produce lumber, e.g., and to do that he needs trees. Third, the passage suggests that the landlord does not deserve this income, but this is imprecise and too quickly put. After all, the landlord might have bought his land with money made through his own diligent labor. In that case, it is at least not obvious that he does not deserve to make money by leasing it. Fourth-and this is critical-whether the landlord gets paid or not, and how much he gets paid, has no effect on the existence of factors of production (i.e. the trees). The land produces its bounty independent of exchange between landlord and laborer. Needless to say, this is not always true when it comes to factors of production. If you do not pay a person her reservation wage-the minimum amount she would accept to do the job-she will not work.

David Ricardo gives a similar definition: "Rent is that portion of the produce of the earth, which is paid to the landlord for the use of the original and indestructible powers of the soil" $(1817,49) .{ }^{9}$ But he makes an important caveat: "[Rent] is often however confounded with the interest and profit of capital" (49).

For example, suppose that the landlord builds roads on his land to facilitate the production of lumber. As a result, his property is more productive, and he receives a commensurately larger income from the

\footnotetext{
${ }^{9}$ See Blaug (1996) for an extensive analysis of the role of rent in classical economic thought.
} 
laborer. Now the landlord's income is not entirely rent; part of it is compensation for his capital investment. It is not rent because if it is not paid, some lumber does not get produced (because the landlord does not build and maintain the roads).

There is, thus, a critical difference between rent and bona fide returns to capital. As a positive matter, the two can be difficult to tell apart, but the normative difference is significant; the former is undeserved income, and the latter, deserved. More on this, and the related idea of 'quasi-rent', in $\S 4$.

The neoclassical definition of economic rent is a generalization of the classical idea: it is any payment to an owner of a factor of production above and beyond what is necessary to bring that factor into economic use. Equivalently, rent is any payment to an owner of a factor of production in excess of that factor's opportunity cost. To show the equivalence, take the simple case of a person choosing between working at company $X$ and leisure. If he values his leisure at $€ 100 /$ hour, then he will work if and only if the wage offered is $>€ 100 /$ hour. And he will accept any wage $>€ 100 /$ hour; he will bring his labor into economic use for $€ 101$ just as well as $€ 1,000$. Why? Because both $€ 101$ and $€ 1,000$ exceed the opportunity cost, which is an hour of leisure, or, equivalently, $€ 100$. This is why any income accruing to unimproved land is rent: its opportunity cost is $€ 0$, you do not have to give anything up to use it, the land is already there. ${ }^{10}$

Thinking about rent from the point of view of general economies, it is plain that whether a person's income is economic rent or not turns not only on his preferences, but on other people's preferences, as well. Make the example (slightly) more realistic by having our economic agent face a choice between (1) a job with company $X$, (2) an hour of leisure, which he values at $€ 100$, and (3) a job with company $Y$, which offers $€ 120$ /hour. Now, if company $X$ offers $€ 121$, our agent will accept, as he would have in the example above. But, unlike above, he will not be extracting $€ 20 /$ hour in rent. The existence of company $Y$ has changed the opportunity cost; it is no longer an hour of leisure (or, equivalently, $€ 100$ ). It is an hour of work with company $Y$ (or, equivalently, €120). Note that this change is exogenous to the agent: $Y$ has offered him this

\footnotetext{
${ }^{10}$ The attentive reader might point out that even unimproved land has alternate uses, and so its opportunity cost is not really $€ 0$. That is true, and was recognized by early neoclassical economists. What is important is not whether a factor commands a rentsince, in the real world, all factors plausibly do-but the extent to which a factor owner's income is rent.
} 
job because of the tastes of its consumers and the profit-maximizing desire of its owners. (The moral implications of this exogeneity will be considered, briefly, in §4.)

In the real world, it is hard to say with precision how much of any given income is rent. Would Clayton Kershaw actually accept \$10 million (rather than \$33 million) to stay in the Major Leagues? Perhaps not, even though at \$10 million the lion's share of his income would remain rent. Perhaps Kershaw would be so offended by the, shall we say, low-ball offer that he would quit baseball in protest. (In fact, there is a straightforward way to model this scenario: for Kershaw, there is an enormous negative compensating differential associated with the job at $\$ 10$ million.)

Also, keep in mind that Kershaw requires a return on his investment in himself. He would not have devoted all those hours to practicing his curveball, year after year, if he didn't believe he was going to get paid for it in the future. Compensation for that investment is not rent.

But these are not challenges to the concept of rent; they are challenges to the real-world identification of rent. And while they are significant challenges, I hope that the next section makes clear that we have good empirical evidence that the problem of rent is severe and growing.

Now, a few conceptual observations about rent. First, payment of rent does not result in additional output; it just rearranges the current ownership of output. Nothing is called into productive use when a rent is paid. A corollary is that rents can be confiscated without introducing any inefficiency into the economy. ${ }^{11}$ Indeed, if some new factor can be brought into use by redistributing the rent, then confiscation is efficiency-enhancing.

Second, any factor of production may obtain a rent. Land is the classical example, but all the same holds true for capital and-saliently in the 21 st century-labor.

Third, although rent may look a lot like economic profit, the two concepts are different. Imagine a widget market that is perfectly competitive in the common sense: buyers and sellers have full information and are price-takers. In this market, in the long-run, no firm makes an economic profit (assume widget technology exhibits constant returns to scale).

\footnotetext{
${ }^{11}$ Henry George (1886) is the most famous proponent of rent confiscation.
} 
One day, Jones, who has exceptional widget-making skill, enters the labor market. A firm hires Jones at his reservation price and thereby starts turning a profit. Other firms recognize this and compete for Jones, bidding up his wage until all profit disappears.

Now we have a market in which (1) there is zero profit but positive rent. (If firms own their own factors of production the net effect may be the same, but that's not the case here.) And, (2) there is perfect competition but there is still rent. Only if factor markets are perfectly competitive will rents not arise.

Fourth, there is a sense in which we ought to worry about rent for the same reason that we ought to worry about profit. If a firm is making a profit in the long-run, that implies that the market is not competitive, and that the economic surplus is less than it might be. And, of course, monopolies are archetypical examples of market failure which most of us would like to correct through government intervention.

Similarly, if the owner of a factor of production is obtaining a rent, that implies that the factor market is not competitive, and that the surplus is less than it might be. It would seem, therefore, that if we ought to worry about monopolies in output markets (which we often do), we ought to worry about rent in factor markets (yet this goes largely unaddressed).

Fifth and finally, we should define that libertarian bugbear, 'rentseeking'. Jason Brennan says that "a firm engages in rent seeking when it seeks to gain an economic privilege or advantage from governmental manipulation of the market environment" $(2012,121){ }^{12}$ For example, a firm might find it profitable to lobby the government to require occupational licensing in its market: that keeps out potential competitors. That's rent-seeking, and it is a particularly libertarian obsession because it is an example of government regulation doing more harm than good.

But the libertarian's focus on this source of rent is unprincipled. The exact same mechanism arises in the private sector all the time. For example, in nursing there are now 183 different certifications (or so nurse.org estimates), none of which has the first thing to do with government regulation. All impede free entry into the labor market (firms can, and many do, exclude from consideration applicants who

${ }^{12}$ A slightly better definition of 'rent-seeking' would be attempts to keep factors of production in fixed supply. These attempts may involve "governmental manipulation of the market environment", or they may not (e.g. the private sector nursing certifications I discuss). 
lack one or more of them) and few serve a useful informational purpose ('Certified Transcultural Nurse'? Give me a break).

Moreover, rents often arise without anyone 'seeking' them at all. The 'beauty premium', to be discussed shortly, is an example: given two people of equal productivity, the beautiful person gets paid more. That premium is a rent, and it is as morally problematic, and as inefficient, as the rent extracted by the lobbying firm which the libertarian rightly finds objectionable. (The libertarian poses no objection to wage premia owing to beauty.)

What should concern us is not whether rent-seeking is good or bad, but whether rents are good or bad. As we shall see, rents are bad. And that is why rent-seeking is bad.

\section{ECONOMIC RENTS ARE UNDESERVED}

Within the distributive justice literature, scant attention has been paid to the topic of economic rent. ${ }^{13}$ The two most important contemporary works-John Rawls' A Theory of Justice and Robert Nozick's Anarchy, State, and Utopia-ignore it completely. The implicit assumption in both these works is that most forms of income share the same moral status. (An exception would be, e.g., income gained through fraud or extortion.)

But we might think that the correct theory of distributive justice draws a moral line between rents, which are in some sense superfluous to economic life, and the factor income that makes our collective prosperity possible. At best, our leading theories can differentiate between the two only on instrumental grounds. (A Rawlsian argument might go like this: 'Rents are inefficient, and therefore their existence is not in the interest of the worst-off'. Whether that is true or not depends on myriad non-ideal facts.) Desert, on the other hand, can point to an intrinsic moral difference between the two.

We begin our analysis of rent by considering the aforementioned beauty premium, first investigated by Hamermesh and Biddle (1994). They found that 'plain' workers suffer a 9\% wage penalty and 'beautiful' workers enjoy a 5\% wage premium, holding all else (education, experience, etc.) equal. The effect is found across professions, and it is not explained by tortuous appeals to productivity (e.g. "beautiful people

${ }^{13}$ The exceptions-in which rent is discussed in any detail-include Fried (1995), Gauthier (1986), Lamont (1997) and (2014), Mack (1992), and Olsaretti (2004). Furthermore, there is extensive libertarian work on rent-seeking. I also refer the reader to Peter Dietsch's essay in this special issue of the Erasmus Journal for Philosophy and Economics, the main argument of which I am sympathetic to. 
are more confident, and thus better workers'). Rather, we provide advantages to attractive people because we like looking at them and being around them. The advantage is purely interpersonal, unconnected to productivity, and so it is a rent.

But is it deserved? It is easy to see that, conceptually, it is not. The beauty premium does not reflect underlying economic contribution, and that, recall, is the (provisional) desert basis.

But really, nuanced analysis is unnecessary. Intuition gets things right. Does Gigi Hadid, 2016 Model of the Year, deserve to make more than the models in the Sears Catalog? Plausibly, yes. But given two surgeons of identical skill, does the pretty one deserve a higher wage than the homely one? Certainly not.

A second source of rent in our economy is nepotism-or what is known euphemistically these days as 'networking'. Nepotism is more pernicious than the beauty premium for two reasons. First, it is more widespread. Second, nepotism wastes resources. Unlike the beauty premium, which a person enjoys more-or-less automatically (set aside money spent on cosmetics, time devoted to grooming, etc.), nepotism is costly. Time is spent searching for contacts; people pay to attend conferences so that they can make connections; LinkedIn gets purchased for $\$ 26$ billion. These resources could be put toward productive enterprise, but they are not. They are used by some to gain an advantage against competitors in the labor market.

To be sure, there are arguments that some of these investments serve a productive function, easing labor market frictions. I am skeptical of those arguments, but in any case, they plainly do not apply to the most egregious examples of nepotism.

One such example is nepotism in executive pay-setting. Bebchuk and Fried (2004) show that executives frequently manipulate their directors into providing compensation far beyond what is justified by profit maximization. That excess is a rent. Further evidence for this phenomenon is provided by Chhaochharia and Grinstein (2009), who find that CEO pay decreases with regulatory oversight, also suggestive of rent extraction via nepotism. (See also Morse, Nanda, and Seru 2011.)

Similarly, there is a literature on the practice of 'options backdating': giving executives stock options which are already in-the-money, by 'granting' them at a past date, when the strike price was lower (see, e.g., Lie 2005; Heron and Lie 2007, 2009; Narayanan and Seyhun 2008). The idea is to make shareholders think that these are incentive 
payments for performance when in fact they are a clever way to conceal double-dealing between executives and directors. These options are rents. And there is independent evidence of rent extraction among top earners from the optimal taxation literature. (See, e.g., Piketty, Saez, and Stantcheva 2014. Zidar forthcoming is also relevant.)

The evidence suggests that much of the income of top earners in the U.S. is rent. Although it is hard to know the extent of the problem, Dean Baker (2016) estimates that four classes of rent, including executive compensation but not exhaustive of all rent, comprise between $6.2 \%$ and $8.5 \%$ of GDP, and that these rents are the principal cause of the income redistribution to the top one percent which we have seen since 1980 .

The moral analysis of nepotism is analogous to that of the beauty premium. These rents are unconnected to contribution or expected contribution, so they are undeserved, so they are not justly held. And we feel the moral difference between (1) an executive being handsomely rewarded for the sage management of her firm, and (2) an executive obtaining the very same income by manipulating her (perhaps witting) directors. The former income is plausibly deserved. The latter is not.

These cases also show why it is unsatisfactory to define economic rent in any of the hand-wavy ways described in §3. Nepotism can be hard work, and so 'income obtained without effort' is not right. Something similar may be said about 'income unconnected to skill'. And luck has nothing to do with the extraction of rents in these cases. (Rentseeking also provides a fine example of why these definitions are lacking; it takes industry and skill, not luck, to manipulate the regulatory environment in one's favor.)

The next source of rent we consider does concern luck, and it introduces complications to the alleged basis for deserved income, viz. contribution. Bertrand and Mullainathan (2000, 2001) show that executives are rewarded equally for performance and for luck: for every $1 \%$ increase in accounting return, CEO pay increases by $2 \%$. The source of the return is irrelevant; the CEO is treated the same no matter whether the return is a result of his performance or exogenous and unforeseeable factors like oil prices. If it is the latter, then the reward is a rent. (See also Garvey and Milbourn 2006.)

Here's the rub: there are cases in which the rent both (1) is obtained through luck, and (2) reflects a genuine contribution on the part of the executive. At the same time, our intuition is that this rent, like the 
others we have considered, is undeserved. This in turn implies that economic contribution simpliciter cannot be the right desert basis.

For example, suppose that we have two firms, $A$ and $B$, which use crude oil as an input to production. At the beginning of each month, the CEOs of $A$ and $B$ decide how much oil to buy for that month.

In January, the CEO of $A$, an intelligent man, bought a certain quantity of oil after careful contemplation and consultation with industry experts. Let us assume, in fact, that this CEO reached a maximally justified belief about future oil prices and purchased the optimal amount of oil for his firm. By contrast, the CEO of $B$, who is stupid and foolhardy, spent all his firm's cash on oil. He had no reason to do this; it was a whim, and it put his firm on the path to bankruptcy.

However, at the beginning of February, a freak earthquake destroys oil infrastructure and sends prices skyrocketing. In these new conditions, $A$ is unable to survive; it shuts down. $B$ has all the oil it needs, and it prospers. Does the CEO of $B$ deserve his salary? It is a rent, to be sure, because it is unconnected to productivity (really, his labor was anti-productive). But it does reflect a contribution; the CEO of $B$, and no one else, is responsible for his firm's profits and its ability to produce goods and services.

This conflicts with intuition. We have a contribution here, but it is a lucky one. It did not result from any laudable character or decisionmaking, and so it is an inappropriate ground for desert. If anything, the CEO of $B$ seems deeply undeserving, while the CEO of $A$ deserves his paycheck. After all, the latter's character is impeccable and his decisionmaking perfect. The fact that it did not, as a contingent matter, lead to an actual contribution does not seem to diminish his desert. ${ }^{14}$ And the fact that the CEO of $B$ did produce an actual contribution does not seem enough to make him deserving.

An analogy may be found in the criminal context. Typically, we do not think that a person deserves punishment unless there is mens rea; unless he intended to commit the crime. (Though the person need not know that the thing that he intended to do was criminal.) If Anne killed Charlie by sprinkling cyanide in his cereal, intending to kill him, Anne

\footnotetext{
${ }^{14}$ This suggests, perhaps, that contribution per se is not a necessary element of desert. The CEO of $A$, after all, appears to be deserving despite making no contribution at all. Although I do not want to explore this matter in detail here, it would seem to fit with the idea of desert, and the aboutness principle (\$2) in particular. Nevertheless, as a practical matter it is hard, maybe impossible, to evaluate contribution-making character independent of actual contribution. In other words, one's actual contribution is the best proxy we have for one's ability to contribute.
} 
deserves to be punished. If Beth killed Charlie by sprinkling cyanide in his cereal, thinking it was sugar, Beth does not deserve to be punished. Same action (same 'contribution'), different mental state-and so different judgments under desert.

Now, one might wonder about 'strict liability' offenses, in which mens rea is not necessary to complete the offense. Doesn't a statutory rapist, for example, deserve to be punished?

I think that ultimately the analogy works out, although it is a little more complicated. For one thing, sometimes these offenders do not deserve to be punished. One imagines a 17-year-old boy who is sent to prison, and forced to register as a sex offender, for mutually agreedupon sex with his 16-year-old girlfriend. (In many U.S. states this is considered rape, on the grounds that the 16-year-old is incapable of providing consent.) Many people (myself included) regard that punishment as unjust. And I suspect that those who try to justify the punishment do so on consequentialist grounds, unrelated to desert and justice.

And for those cases in which we do judge the offender as deserving punishment, our judgment involves a negative assessment of the offender's character. We say things like, 'he should have known better', or 'he should not have taken her word that she was 17'. The person's character is essential to determining what he deserves.

The conceptual issue here involves the aboutness principle (§2). There must be a proper link between desert basis and desert subject if the desert-claim is to be bona fide. In the first case discussed, the basis is not about the subject in any substantive way; if anything, the contribution is about factors wholly exogenous to the subject (e.g., the earthquake). This point can be made salient with stronger precisifications of the aboutness principle: the CEO was not responsible for the economic contribution, nor did he control it. So he cannot deserve on the basis of it.

Let us consider one more important source of rent in our economy, the so-called 'superstar' phenomenon (Rosen 1981). In some markets, small differences in skill give rise to enormous differences in reward. This is for two reasons: first, there is inadequate competition, which allows the superstar to extract rent; and second, the superstar is able to reach many customers at low marginal cost.

Athletes, singers, actors, and celebrities generally provide the best examples of superstars. There are legions of singers who are only 
slightly less talented than Katy Perry, but these singers don't make slightly less money than Perry-they make almost no money. Why? Because music-lovers, no matter where they live, can just as easily buy a Katy Perry song as they can patronize a local musician. And because Katy Perry's product is regarded as unique or close to it, most of Perry's $\$ 33$ million income is rent. ${ }^{15}$ While we do not know exactly how Perry reckons her opportunity costs, doubtless she would do what she does for much less than this. The same goes for superstar actors, athletes, and so on.

Similar to the previous examples, superstar earnings drive a wedge between contribution and desert. Superstars do make a large contribution to the economy; people consume their product, and that creates widespread value in the form of entertainment. And superstars are paid commensurate with that large contribution. Conversely, there are legions of local musicians, AAA baseball players, et al. who struggle to make a living wage. These non-superstars make small contributions.

This is objectionable from the desertist perspective. It is desert's raison d'être to balance (1) a mode of treatment-whether it's punishment for a crime or income for one's labor-with (2) relevant facts about one's character. And, in particular, it is about ensuring that (1) and (2) vary in proportion. ${ }^{16}$ The greater the wrongdoing, the worse the deserved punishment. Similarly, the greater the, let's say, meritorious economic contribution, the bigger the deserved income.

The phenomenon of superstars, and the above analysis of contribution-based-on-luck, suggest that to determine one's economic deserts we must scrutinize not just one's contribution but one's character as well. To be sure, it cannot be character in a vacuum that makes one deserving (the most skilled widget-maker in the world does not deserve a high income if he is not making widgets). But insofar as one is making an economic contribution, differences in character give rise to differences in deserts.

\footnotetext{
${ }^{15}$ Forbes (2018).

${ }^{16}$ This is, indeed, the notion of proportional equality which underlies Aristotle's desertbased approach in the Nicomachean Ethics. Just equality is, for Aristotle, equality between the ratios of desert objects to desert bases. Although most associated with Aristotle, proportional equality is also commended by Plato in the Laws: "By distributing more to what is greater and smaller amounts to what is lesser, it gives due measure to each according to their nature: this includes greater honors always to those who are greater as regards virtue, and what is fitting-in due proportion-to those who are just the opposite as regards virtue and education. Presumably this is just what constitutes for us political justice" (757c).
} 
I stress that the desertist does not object to superstars being paid more than non-superstars. The superstar rent is based on an underlying difference in character; the superstar is genuinely more talented than the non-superstar. What the desertist objects to is that part of superstars' salaries arising from their market power.

If we have robust labor market competition, our superstars will be paid a premium over their non-superstar counterparts, proportional to the difference between their productive abilities. That premium will be deserved in full.

If we do not have robust competition, as is the case in the actual world, our superstars will be paid a premium over their non-superstar counterparts, but that premium will not be proportional to the difference between their productive abilities. And it will not be deserved in full (only in part). For some of that premium comes not through talent but through superstars' price-setting (which is possible owing to the imperfect competition). The superstar reduces economic output and social welfare in order to enjoy greater personal gains. ${ }^{17}$ He does not deserve reward for this.

Now I think that there is an interesting objection, alluded to in $\S 3$, to this whole way of thinking about character, contribution, and desert. To wit: there is a sense in which even one's own talent is exogenous. For other people-consumers-decide which of one's skills, character traits, etc. are economically relevant, via their consumption decisions. Clayton Kershaw has 'talent' only because people think that propelling a cowhide ball off a mound of dirt is a useful thing to do. If consumer tastes were to change, Kershaw's deserts would seem to disappear. But how can that be in light of the aboutness principle (§2)? If facts about other people should not affect one's own deserts?

Reply: for better or worse, in the neoclassical conception, value is determined by the subjective preferences of market actors. ${ }^{18}$ Within this

\footnotetext{
17 Theory only guarantees that this market power leads to a loss of welfare as measured in monetary units (dollar, euro, etc.). It is theoretically possible, although almost surely not the case in practice, that welfare as measured in utility could increase-if the superstar's marginal utility of consumption is sufficiently greater than that of those whose surplus gets reduced.

${ }^{18}$ Let me give my basic take on value here (I discuss these matters in more detail in Chapter 6 of my 2018 book and hope to consider them at length in future work). Neoclassical economics says that things have value just in case they are desired by people. There are problems with this definition. For one thing, it entails that one creates value, and that one may be deserving, if one produces a popular product which caters to depraved tastes (imagine a song, which people love and consume, whose lyrics are a racist rant). Such a scenario serves, I believe, as a counterexample to the
} 
conception, we can only talk about economic contribution with reference to consumer demand. When we say that Jones is making a contribution, we mean that when he provides his labor (or his capital, etc.) some consumers' preferences are satisfied that otherwise would not be.

Here is an analogy: we do not think that the best curling team at the Winter Olympics does not deserve the gold medal just because the sport of curling is highly arbitrary. The sport exists. Why it exists, and whether it should exist, are interesting questions, but they are not relevant for talking about what people deserve within it. Economic life is similar. It is one thing to inquire about the nature of value; it is another thing to scrutinize, given a fixed understanding of value, who has contributed to the creation of that value and in what measure. And it is through such considerations that one's just deserts are determined.

An issue which should be addressed is the moral status of the aforementioned quasi-rents. A quasi-rent is a payment to a factor of production which looks, on its face, like a rent, but which is in fact an inducement to productive enterprise. A typical example is a pharmaceutical company that is granted a patent on a new drug. The patent gives the company monopoly power, and so it appears to extract a rent on the basis of a scarce factor (viz. the patent).

But looking a little closer, we can see that this is not the case. Without the possibility of patent protection, the drug would not have been developed to begin with. It was the possibility of monopoly profit that enticed the firm to make the multi-billion-dollar research and development investment. This is different from most markets, in which no such protection is necessary for innovation, and monopoly profits are deadweight loss. ${ }^{19}$

Indeed, far from being unjustly held, these quasi-rents are essential to a well-functioning economy. Their existence, and the quest for them,

naïve account of subjective value. Better, I think, to hold that (1) value is ultimately objective, and (2) the best way to identify what things have value is through the market-i.e. by treating value as if it were subjective. In this way, we can maintain an objective understanding of value without abandoning the neoclassical economic framework.

${ }^{19}$ An anonymous referee has pointed out to me that there is a case to be made that income gained through pharmaceutical patent protection is rent (and therefore unjustly gained on my account) because there are alternative mechanisms available for drug development. Dean Baker makes such a case, and his 2004 paper summarizes these alternative mechanisms. I myself am not sure what to think now. So I shall just say that income gained through this kind of patent protection is often thought to be quasi-rent. To the extent that it is, it does not disrupt a desert-based distributive system. 
make possible the cycle of 'creative destruction' (Schumpeter 1934) on which so much prosperity relies. As Eric Mack says:

[...] in actual competitive economies [...] insightful entrepreneurs will not imitatively ape the production and marketing of others; they will search out new ways of producing for new or as-yet-unexploited markets. [...] seek[ing] not less but more in the way of imperfectly competitive returns. [...] The perfectly competitive market idealization draws our attention away from the way in which actual competition enhances value and knowledge in society through a process whose participants aim at, and sometimes achieve, higher (than normally imperfectly competitive) returns (Mack 1992, 178179).

But observe how none of the forms of rent extraction discussed in this section comports with this description. The beauty premium is a pure interpersonal advantage; nepotism stifles innovation rather than encourages it (among other things, it disincentivizes human capital development); the superstar does not require his monopoly to work; and so on.

As I mentioned in $\S 3$, libertarians are quick to criticize rent-seeking. Why? Because it provides them ammunition in their anti-government cause. But libertarians fail to appreciate that other rents, no less pernicious, arise elsewhere in the economy and have nothing to do with government. Pace many libertarians, not all high incomes reflect "insight", nor the exploration of "yet-unexploited markets", nor the creation of "value and knowledge". That is, not all high incomes are quasi-rents, even though the libertarian would like to believe that they are. The sources of income I have surveyed in this section are not trivial, and they cannot be justified on the grounds Mack gives.

Now let us assume that rents are undeserved, and that, therefore, people have no claim of justice on them. Let us further assume that the government can confiscate them effectively. What then? Whom should they be transferred to?

As a non-ideal matter, this is of course complicated. But some philosophers think that it is intractable even in the ideal case. In discussing Nozick's (1974) 'Wilt Chamberlain' example, Mack (1992) wonders what could possibly be a principled way to redistribute Wilt's ill-gotten gains. ${ }^{20}$ Mack muses that "it seems odd [...] that the economic

\footnotetext{
${ }^{20}$ Although Nozick does not say so, Wilt (in the example and in real life) is a fine example of rent extraction via the superstar effect.
} 
rent that accrues to Chamberlain should be distributed across all members of Chamberlain's society" (1992, 182). I agree. But there is no reason why the government must be so indiscriminate.

From the point-of-view of desert, we should like to both (1) confiscate rents (because they are undeserved), and (2) give transfer payments to those who have less than they deserve. And it would be most elegant if (1) and (2) were equal-so that the perfectly just balance (n. 16) may be achieved.

In fact, (1) and (2) will be equal! Think of a competitive economy with production operating under constant returns to scale. The owner of each factor of production receives an income equal to that factor's marginal product, which is (barely) sufficient to compensate for opportunity costs. National income equals the sum of marginal products.

One day, the owner of some factor is able to extract a rent. Because the rent payment does not create more output, it must come at the cost of another's income. But all shares were perfectly deserved beforehand. So someone now must be getting less than she deserves. Therefore, the right response is to confiscate the rent and give it to the owner of the factor earning less than she deserves. ${ }^{21}$

What about the case of decreasing returns-to-scale? (Increasing returns-to-scale being incompatible with the assumption of perfect competition.) Now there will be income left over after each factor is paid its marginal product. The natural solution for the desertist is to say that people deserve income in proportion to their marginal products. Then the same argument given for the constant returns-to-scale case goes through. I note that Roemer and Silvestre (1993) have proven that there exists such an equilibrium for general economies-factor shares paid in proportion to their marginal products-and that it is Pareto efficient.

Let me conclude this section by suggesting a taxonomy of rents. We have identified five types.

Type One rents derive from natural features that provide one with an interpersonal advantage in the labor market. The beauty premium is

\footnotetext{
${ }^{21}$ At this stage of the argument, there is an implicit assumption that marginal product is a good measure of 'contribution'. This is not trivial, although it has been endorsed by others; most famously, Clark (1899), and more recently, Mankiw (2013). I give a fuller defense of the assumption in Chapter 6 of my 2018 book. N.B. while Mankiw and I agree normatively-we think that justice is about giving people what they deserve, that one's deserved income is based in one's contribution, and that marginal product is the right measure of 'contribution'-we disagree, positively. He believes that America's high labor incomes reflect contributions; I believe that they do not.
} 
a Type One rent. Of course, that beauty provides one an extra income is not a natural fact but a social fact-and a lamentable one at that. (Also a correctable one.) But the rent-producing feature is natural, and so it belongs to the first type.

Type Two rents derive from social features that provide an interpersonal advantage. Nepotism is a Type Two rent. Again, these are more pernicious than Type One rents because resources must be spent to create or maintain the advantage. (Here we may also include rents derived from non-natural beauty. Some people undergo surgical procedures in order to look more beautiful, in order to, inter alia, improve their job prospects.)

Type Three rents occur when a person receives an economic reward which is unconnected to underlying productive capacity. Our incompetent but lucky CEO provides an example.

Type Four rents result from natural scarcity. Returns to unimproved land and some superstar salaries are examples.

Type Five rents result from artificial scarcity, which is usually (but not necessarily) cultivated by the factor enjoying the rent. That is, Type Five rents are the result of rent-seeking.

Let me suggest one more type: Type Six rents, defined as rents gained through 'unproductive financial activity'. The hedge fund that exploits a technical inefficiency in the market, moving money from others' pockets to its own without growing the economic pie, is an extractor of Type Six rent. Similar to Type Two rents, Type Six rents are undesirable because they squander resources which might be put to productive use. Because of the enormous (undeserved) incomes involved, hedge funds, private equity firms, and the like are among the most-desired employment destinations for graduates of top universities (see, e.g., Goldin and Katz 2008). This is significant human capital which could be put toward scientific research, or education, or widgetmaking-or whatever-but is not.

It can be difficult to distinguish Type Six rents from quasi-rents. There are cases to be made-unpersuasive ones, in my opinion-that these parts of the finance industry do serve bona fide productive purposes. Maybe they provide liquidity in markets or help firms work more efficiently. If so, then they are deserved and justly held. This is a positive matter, to be settled through empirical research. 


\section{What Does This Mean for Public Policy?}

The argument to this point may seem recherché. In fact, I think that these considerations of rent and desert have important practical ramifications.

For one thing, they justify economic redistribution-away from undeserving extractors of rents to citizens who have less than they deserve. And the redistribution is morally plausible, in the sense that it accords with the widespread sentiment that there is too much economic inequality. If we confiscated and redistributed rents as described, we would significantly reduce inequality. (Rent extraction overwhelmingly happens at the top, not the bottom, of the income distribution. And it comes at the cost of low- and middle-income earners owing to differentials in bargaining power.)

Keep in mind that we desertists do not care a whit about economic equality or inequality (of outcome). What we care about is matching people's rewards to their contributions. These contributions are unequal, and so just rewards are unequal. It simply happens to be the case that actual contributions are not so unequal as actual wages would suggest. In other words, real-world inequality is a symptom of injustice rather than an injustice in itself.

In contrast, the libertarian would protect rents (maybe not Type Five rents), as they are a result of free exchanges in the market. But let's think about what this means in practice. First, because the marginal utility of rents is virtually nil (those who extract them are already rich), they have no positive effect on welfare. Second, they are an economic inefficiency, making the social surplus less than it could be. Third, as we have seen, rents are, at best, imperfectly connected to merit, effort, skill, contribution, and the like, and at worst utterly unconnected. Rather than a modus ponens from libertarian principles to protecting rents, we have a modus tollens: no correct theory of justice will hold that these rents should be protected.

It is important that people not regard 'contribution-based income' as reactionary, for it is anything but. As I have argued (Mulligan 2018), the distributive system I commend would produce a society more egalitarian than the most egalitarian c. 2018, even as the system is indifferent to inequality. And really: how reactionary could it be, given that Marx approved of it for his penultimate, socialist phase of history? ("Marx is more a meritocrat than Rawls, Nielsen, Dworkin, and most contemporary liberal political philosophers" [Pojman 1999, 93].) 
Moreover, there are plausible forms of market failure in which people making bona fide contributions go unremunerated. One example is stay-at-home parents. They serve a vital economic function, sustaining the labor force of the next generation and improving its human capitalbut they are not paid for it. (Most do, of course, enjoy psychic utility by doing their parental duty.) In principle, transfers to stay-at-home parents are not only compatible with the meritocratic approach but required by it.

There is also the matter of the Solow residual, or what is now known as 'total factor productivity' (TFP). This is the portion of output not explained by known inputs to production; typically labor and capital. ${ }^{22}$ TFP captures output resulting from technology, institutional change, and synergies among workers. Because TFP is a residual, it is best understood as a measure of our ignorance about inputs to production. After all, some people out there created the technology TFP measures; and so they made the relevant contributions, and so they deserve on the regular grounds. To be sure, it can be hard to say exactly who contributed to production and in exactly what measure. But this is an epistemic challenge of the sort that all distributive principles face. It is not a conceptual challenge.

Finally, a parochial political point: Americans should think hard about why the left has failed to improve the material condition of the lower and middle classes over the past 40 years. It failed to forestall the tax-and-transfer policies, deregulation, and weakening of worker bargaining power which have had the net effect of redistributing income and wealth to the rich. It is illustrative that the major 'progressive' policy achievement of recent years-the Patient Protection and Affordable Care Act-is anything but radical, and its survival unclear.

This failure is especially mystifying given the appetite for progressive redistribution. Americans across ideological lines regard their economy as unfair (Fingerhut 2016), and they are amenable to taxand-transfer policies and new social programs in the name of fairness:

In order to provide both genuine opportunity and a measure of economic security-large majorities of Americans favor a number of specific government programs [...]. Support for these government

\footnotetext{
${ }^{22}$ One may wonder why capital income is deserved. The reason is that a desert-based society must, by conceptual necessity, be built upon robust equal opportunity (Mulligan 2018). There can be no inheritance, e.g. When an individual living in a desertbased society earns capital income, that income can be traced to his contributions.
} 
programs comes from all sectors of society: from Republicans, from self-described middle-class and upper-class people, from whites, and from those with high incomes, as well as from Democrats, workingclass people, African Americans, and lower-income citizens (Page and Jacobs 2009, 22-23).

Why has the American left so struggled? The answer, I think, is that it has based its arguments in moral principles that are widely regarded as false, and used rhetoric that human beings find profoundly unattractive.

If there is a watchword of the American left, it is 'equality'. But we know that equality is rejected as a norm of justice: "Empirical studies provide almost no support for egalitarianism, understood as equality of outcomes, or for Rawls's difference principle" (Konow 2003, 1199).

In contrast, there is overwhelming support for the idea that justice is a matter of giving people what they deserve, and that, when it comes to income, just deserts are indexed to contribution. This is probably the best demonstrated result in the enormous empirical literature on justice, supported by research in social psychology, child development, experimental economics, evolutionary theory, neurology, and other fields.

The degree of support for justice-as-desert is so humongous that I cannot begin to describe it here (I devote Chapter 3 of my 2018 book to the task), but one easily gets a sense of things. As Gregory Mankiw points out:

[...] people are rarely outraged when high incomes go to those who obviously earned them. When we see Steven Spielberg make blockbuster movies, Steve Jobs introduce the iPod, David Letterman crack funny jokes, and J.K. Rowling excite countless young readers with her Harry Potter books, we don't object to the many millions of dollars they earn in the process. The high incomes that generate anger are those that come from manipulating the system. The CEO who pads the corporate board with his cronies and the banker whose firm survives only by virtue of a government bailout do not seem to deserve their multimillion dollar bonuses. The public perceives them (correctly or incorrectly) as getting more than they contributed to society (Mankiw 2010, 295).

The objectionable incomes which Mankiw identifies are all rents.

It is therefore worth asking if we might arrive at the society that we regard as pretheoretically just via a different, non-egalitarian, normative route. The argument of this paper is that the answer is 'yes'. If justice is 
a matter of giving people what they deserve, then we ought to confiscate and redistribute rents. This is just, and it has the side-effects of reducing inequality, increasing economic efficiency, and political expediency.

It would be a mistake to stop there, though. At a time when we are revisiting everything that we have taken for granted about political and social culture, we should take a hard look at the normative frameworks that have so occupied us as philosophers. Perhaps their time has passed. I am convinced that before long, justice will be found in the venerable but neglected idea that we should give people what they deserve.

\section{REFERENCES}

Ake, Christopher. 1975. “Justice as Equality.” Philosophy \& Public Affairs 5 (1): 69-89.

Allen-Hermanson, Sean. 2017. "Leaky Pipeline Myths: In Search of Gender Effects on the Job Market and Early Career Publishing in Philosophy." Frontiers in Psychology 8 (953): 1-10.

Baker, Dean. 2004. "Financing Drug Research: What Are the Issues?" Center for Economic and Policy Research. <http://cepr.net/documents/publications/ intellectual_property_2004_09.pdf $>$.

Baker, Dean. 2016. "The Upward Redistribution of Income: Are Rents the Story?" Review of Radical Political Economics 48 (4): 529-543.

Bebchuk, Lucian, and Jesse Fried. 2004. Pay Without Performance: The Unfulfilled Promise of Executive Compensation. Cambridge, MA: Harvard University Press.

Becker, Gary S. 1957. The Economics of Discrimination. Chicago, IL: University of Chicago Press.

Bertrand, Marianne, and Sendhil Mullainathan. 2000. "Agents With and Without Principals." The American Economic Review 90 (2): 203-208.

Bertrand, Marianne, and Sendhil Mullainathan. 2001. "Are CEOs Rewarded for Luck? The Ones Without Principals Are.” The Quarterly Journal of Economics 116 (3): 901-932.

Blaug, Mark. 1996. Economic Theory in Retrospect. 5th ed. Cambridge: Cambridge University Press.

Brennan, Jason. 2012. Libertarianism: What Everyone Needs to Know ${ }^{\circledast}$. New York, NY: Oxford University Press.

Chhaochharia, Vidhi, and Yaniv Grinstein. 2009. "CEO Compensation and Board Structure." The Journal of Finance 64 (1): 231-261.

Clark, John B. 1899. The Distribution of Wealth: A Theory of Wages, Interest and Profit. New York, NY: Macmillan Company.

Corak, Miles. 2013. "Inequality from Generation to Generation: The United States in Comparison." In The Economics of Inequality, Poverty, and Discrimination in the 21st Century. Volume I - Causes, edited by Robert S. Rycroft, 107-126. Santa Barbara, CA: Praeger.

Dicey Jennings, Carolyn, Angelo Kyrilov, Patrice Cobb, Justin Vlasits, David W. Vinson, Evette Montes, and Cruz Franco. 2015. "Academic Placement Data and Analysis: 
2015 Final Report." The Academic Placement Data and Analysis Project. http://dailynous.com/wp-content/uploads/2016/04/apdafinalreport2015.pdf.

Dick, James C. 1975. "How to Justify a Distribution of Earnings." Philosophy \& Public Affairs 4 (3): 248-272.

Feinberg, Joel. 1963. “Justice and Personal Desert.” In NOMOS VI: Justice, edited by Carl J. Friedrich and John W. Chapman, 69-97. New York, NY: Atherton Press.

Feldman, Fred. 2016. Distributive Justice: Getting What We Deserve from Our Country. New York, NY: Oxford University Press.

Fingerhut, Hannah. 2016. "Most Americans Say U.S. Economic System is Unfair, but High-Income Republicans Disagree." Pew Research Center. http://www.pewresearch.org/fact-tank/2016/02/10/most-americans-say-u-seconomic-system-is-unfair-but-high-income-republicans-disagree/.

Freeman, Samuel. 2007. Rawls. New York, NY: Routledge.

Fried, Barbara. 1995. "Wilt Chamberlain Revisited: Nozick's "Justice in Transfer" and the Problem of Market-Based Distribution.” Philosophy \& Public Affairs 24 (3): 226245.

Forbes. 2018. “\#19 Katy Perry.” Accessed June 18, 2018. https://www.forbes.com/profile/katy-perry/.

Garvey, Gerald T., and Todd T. Milbourn. 2006. "Asymmetric Benchmarking in Compensation: Executives Are Rewarded for Good Luck but Not Penalized for Bad.” Journal of Financial Economics 82 (1): 197-225.

Gauthier, David. 1986. Morals by Agreement. New York, NY: Oxford University Press.

George, Henry. 1886. Progress and Poverty: An Inquiry into the Cause of Industrial Depressions, and of Increase in Want with Increase of Wealth-The Remedy. London: Kegan Paul, Trench \& Co.

Goldin, Claudia, and Lawrence F. Katz. 2008. "Transitions: Career and Family Life Cycles of the Educational Elite." The American Economic Review: Papers and Proceedings 98 (2): 363-369.

Hamermesh, Daniel S., and Jeff E. Biddle. 1994. "Beauty and the Labor Market." The American Economic Review 84 (5): 1174-1194.

Heron, Randall A., and Erik Lie. 2007. "Does Backdating Explain the Stock Price Pattern around Executive Stock Option Grants?" Journal of Financial Economics 83 (2): 271-295.

Heron, Randall A., and Erik Lie. 2009. "What Fraction of Stock Option Grants to Top Executives Have Been Backdated or Manipulated?" Management Science 55 (4): 513-525.

Hospers, John. 1961. Human Conduct: An Introduction to the Problems of Ethics. New York, NY: Harcourt, Brace \& World.

Hurka, Thomas. 2003. "Desert: Individualistic and Holistic." In Desert and Justice, edited by Serena Olsaretti, 45-68. Oxford: Clarendon Press.

Kagan, Shelly. 2012. The Geometry of Desert. New York, NY: Oxford University Press.

Kleinig, John. 1971. "The Concept of Desert.” American Philosophical Quarterly 8 (1): 71-78.

Konow, James. 2003. "Which is the Fairest One of All? A Positive Analysis of Justice Theories.” Journal of Economic Literature 41 (4): 1188-1239.

Lamont, Julian. 1995. "Problems for Effort-Based Distribution Principles." Journal of Applied Philosophy 12 (3): 215-229. 
Lamont, Julian. 1997. "Incentive Income, Deserved Income and Economic Rents." Journal of Political Philosophy 5 (1): 26-46.

Lamont, Julian. 2014. "University Education Fees, Economic Rents and Distributive Justice.” Journal of Applied Philosophy 31 (3): 287-306.

Lie, Erik. 2005. "On the Timing of CEO Stock Option Awards." Management Science 51 (5): 802-812.

Mack, Eric. 1992. "Gauthier on Rights and Economic Rent." Social Philosophy and Policy 9 (1): 171-200.

Mankiw, N. Gregory. 2010. "Spreading the Wealth Around: Reflections Inspired by Joe the Plumber." Eastern Economic Journal 36 (3): 285-298.

Mankiw, N. Gregory. 2013. "Defending the One Percent." Journal of Economic Perspectives 27 (3): 21-34.

Mazumder, Bhashkar. 2005. "The Apple Falls Even Closer to the Tree than We Thought: New and Revised Estimates of the Intergenerational Inheritance of Earnings." In Unequal Chances: Family Background and Economic Success, edited by Samuel Bowles, Herbert Gintis, and Melissa O. Groves, 80-99. Princeton, NJ: Princeton University Press.

McLeod, Owen. 1996. "Desert and Wages.” Utilitas 8 (2): 205-221.

Miller, David. 1976. Social Justice. Oxford: Clarendon Press.

Miller, David. 1989. Market, State, and Community: Theoretical Foundations of Market Socialism. Oxford: Clarendon Press.

Miller, David. 1999. Principles of Social Justice. Cambridge, MA: Harvard University Press.

Milne, Heather. 1986. "Desert, Effort and Equality." Journal of Applied Philosophy 3 (2): 235-243.

Morse, Adair, Vikram Nanda, and Amit Seru. 2011. "Are Incentive Contracts Rigged by Powerful CEOs?” The Journal of Finance 66 (5): 1779-1821.

Mulligan, Thomas. 2018. Justice and the Meritocratic State. New York, NY: Routledge.

Narayanan, M. P., and H. Nejat Seyhun. 2008. "The Dating Game: Do Managers Designate Option Grant Dates to Increase their Compensation?" The Review of Financial Studies 21 (5): 1907-1945.

Nozick, Robert. 1974. Anarchy, State, and Utopia. New York, NY: Basic Books.

Olsaretti, Serena, ed. 2003. Desert and Justice. New York, NY: Oxford University Press.

Olsaretti, Serena. 2004. Liberty, Desert and the Market: A Philosophical Study. New York, NY: Cambridge University Press.

Page, Benjamin I., and Lawrence R. Jacobs. 2009. Class War? What Americans Really Think About Economic Inequality. Chicago, IL: University of Chicago Press.

Piketty, Thomas, Emmanuel Saez, and Stefanie Stantcheva. 2014. "Optimal Taxation of Top Labor Incomes: A Tale of Three Elasticities." American Economic Journal: Economic Policy 6 (1): 203-271.

Pojman, Louis. 1999. "Merit: Why Do We Value It?" Journal of Social Philosophy 30 (1): 83-102.

Rachels, James. 1978. "What People Deserve." In Justice and Economic Distribution, edited by John Arthur and William H. Shaw, 167-196. Englewood Cliffs, NJ: Prentice-Hall.

Rawls, John. 1971. A Theory of Justice. Cambridge: Belknap Press.

Ricardo, David. 1817. On the Principles of Political Economy and Taxation. London: John 
Murray.

Riley, Jonathan. 1989. "Justice under Capitalism." In NOMOS XXXI: Markets and Justice, edited by John W. Chapman and J. Roland Pennock, 122-162. New York, NY: New York University Press.

Roemer, John E., and Joaquim Silvestre. 1993. "The Proportional Solution for Economies with Both Private and Public Ownership." Journal of Economic Theory 59 (2): 426-444.

Rosen, Sherwin. 1981. "The Economics of Superstars." The American Economic Review 71 (5): 845-858.

Sadurski, Wojciech. 1985. Giving Desert Its Due: Social Justice and Legal Theory. Dordrecht: D. Reidel Publishing Company.

Schumpeter, Joseph A. 1934. The Theory of Economic Development: An Inquiry into Profits, Capital, Credit, Interest, and the Business Cycle. Translated by Redvers Opie. Cambridge, MA: Harvard University Pres.

Sher, George. 1987. Desert. Princeton, NJ: Princeton University Press.

Smith, Adam. 1784. An Inquiry into the Nature and Causes of the Wealth of Nations. London: A. Strahan and T. Cadell.

Williams, Wendy M., and Stephen J. Ceci. 2015. "National Hiring Experiments Reveal 2:1 Faculty Preference for Women on STEM Tenure Track." Proceedings of the National Academy of Sciences of the United States of America 112 (17): 5360-5365.

Zidar, Owen. Forthcoming. "Tax Cuts for Whom? Heterogeneous Effects of Income Tax Changes on Growth and Employment." Journal of Political Economy.

Thomas Mulligan is a visiting scholar at Georgetown University's Institute for the Study of Markets and Ethics, where he conducts research in, primarily, economic justice and collective decision-making. $\mathrm{He}$ is the author of the 2018 monograph, Justice and the Meritocratic State.

Contact e-mail: <thomas.mulligan@georgetown.edu> 